\title{
Pelanggaran Hak Cipta Oleh Korporasi Ditingkat Daerah
}

Oleh:

Ame Raysara dan Nomansar

\begin{abstract}
Abstrak
Hak Cipta merupakan salah satu jenis atau macam hak yang ada dalam HaKI (Hak Kekayaan Intelektual). Hak cipta ini merupakan salah satu jenis hak yang sering dilanggar karena hak cipta merupakan hak yang paling banyak ada di Indonesia. Pelanggaran hak cipta ini menarik dibahas ketika itu dilakukan oleh perusahaan atau korporasi. Menariknya lagi ketika pelanggaran tersebut dilakukan di tingkat daerah. Apakah yuridis atau hukum hak cipta tersebut juga diatur dalam suatu penetapan melalui peraturan daerah? Tentu jawaban dari pembahasan peneliti telah ada yakni bisa saja, tapi tidak terlalu penting untuk diatur karena akibat hukum dari pelanggaran hak cipta ini menjadi urusan daripada tingkat pemerintah pusat Indonesia. Selain itu yang memeriksa dan mengadili perkara ini juga bukan domain daripada pemerintah daerah tapi pemerintah pusat.
\end{abstract}

Kata Kunci: Pelanggaran Hak Cipta, Korporasi, Ditingkat Daerah 
Volume 8 Nomor 1

legal article

\section{REFEREN S I}

Undang-Undang Republik Indonesia Nomor 28 Tahun 2014 Tentang Hak

Cipta.Undang-Undang Republik Indonesia Nomor 24 Tahun 2011 tentang Badan Penyelenggara Jaminan Sosial.

https://media.neliti.com/media/publications/14168-ID-kajian-hukum-hak-pencipta-

atas-lagu-ciptaan-yang-telah-diperjanjikan-pada-pihak.pdf

Telaumbanua, Dalinama. 2017. "Analisis Putusan Judex Facti Tentang Hak Cipta (Studi

Putusan Nomor 05/HKI. Hak Cipta/2016/PN Niaga. Sby)." JURNAL EDUCATION

AND DEVELOPMENT. vol. 6, no. 5

https://www.hukumonline.com/klinik/detail/ulasan/lt5cd3b13c3b4be/gugatan-

pelanggaran-hak-cipta-jika-ciptaan-belum-dicatatkan/

http://digilib.unila.ac.id/11144/

Telaumbanua, Dalinama. 2018. "Pembentukan Peraturan Daerah

Kabupaten/Kota." Jurnal Education and Development. vol. 4, no. 1

Telaumbanua, Dalinama. 2018. "Pembentukan Peraturan Daerah

Kabupaten/Kota." Jurnal Education and Development. vol. 4, no. 1

Telaumbanua, Dalinama. 2015. "Pertanggungjawaban Pidana Korporasi Di Bidang

Lingkungan HiduP." Refleksi Hukum: Jurnal Ilmu Hukum. vol. 9, no. 1

https://www.academia.edu/36355977/PERTANGGUNGJAWABAN_PIDANA_KORPO

RASI_TERHADAP_KEJAHATAN_HAK_CIPTA

http://eprints.undip.ac.id/61266/ 


\section{Volume 8 Nomor 1}

legal article

Sembiring, S. (2002). Prosedur dan Tata Cara Memperoleh Hak Kekayaan Intelektual Di Bidang Hak Cipta Paten Dan Merek. Yrama Widya.

Goldstein, P. (1997). Hak Cipta: Dahulu, Kini dan Esok. Yayasan Obor Indonesia.

Kusmawan, D. (2014). Perlindungan Hak Cipta Atas Buku. Perspektif, 19(2), 137-143.

Rahayu, D. 2011 . "Perlindungan Hukum Terhadap Hak Cipta Motif Batik Tanjungbumi Madura." Mimbar Hukum-Fakultas Hukum Universitas Gadjah Mada, vol. 23, No.1.

Thalib, P. 2013. "Perlindungan Hukum Terhadap Pemegang Hak Cipta Dan Pemilik Lisensi Rekaman Berdasarkanundang-Undang Tentang Hak Cipta" Yuridika, vol. 28 , no. 3 